\title{
Lingkungan Ramah Anak pada Sekolah Taman Kanak-Kanak
}

\author{
Ayu Oktira Diyanti, Chairil Budiarto Amiuza, Triandriani Mustikawati
}

Jurusan Arsitektur Fakultas Teknik Universitas Brawijaya

Email: oktiradiyanti@gmail.com

\begin{abstract}
ABSTRAK
Lingkungan fisik mempunyai peran penting dalam masa tumbuh kembang anak terutama pada masa golden age (0 - 6 tahun) karena paling sering ditangkap langsung oleh panca indera anak. Selain lingkungan rumah, lingkungan fisik yang memilliki intensitas interaksi yang tinggi dengan anak adalah lingkungan sekolah, sebagai contoh adalah taman kanak-kanak (TK). Oleh karena itu, lingkungan TK harus menyediakan fasilitas yang sesuai dengan kebutuhan tumbuh kembang dan karakteristik anak. Tujuan dari penelitian ini adalah mengidentifikasi kriteria lingkungan ramah anak pada sekolah TK. Metode yang digunakan adalah metode komparasi literatur mengenai kriteria ramah anak pada sekolah TK. Dari penelitian ini diketahui bahwa kriteria lingkungan ramah anak pada sekolah TK meliputi tiga faktor, yaitu keamanan, kenyamanan, dan stimulasi pada elemen ruang luar dan ruang dalam sebuah TK. Penerapan faktor-faktor tersebut pada desain sekolah TK meliputi elemen ruang luar dan ruang dalam TK.
\end{abstract}

Kata kunci: anak, taman kanak-kanak, ruang luar, ruang dalam

\begin{abstract}
Physical environment (in this case is kindergarten) needs to be considered because it has a frequent contact either physically or mentally with children. Based on this issue, kindergarten should provides facilities that appropriate to children's growth and development process, and also to their characteristic. The purpose of this research was identifying child-friendly environment criterias. The method used was literature comparation about child-friendly criterias in kindergarten. The result showed that child-friendly criterias in kindergarten were three factors: safety, comfort, and stimulation either in exterior element or interior element of kindergarten environment.
\end{abstract}

Keywords: children, kindergarten, exterior, interior

\section{Pendahuluan}

Anak berusia 0-6 tahun (golden age) perlu mendapat perhatian khusus karena masa tersebut merupakan masa terjadinya perkembangan dan pertumbuhan yang pesat sekaligus kritis karena merupakan langkah awal masa depan anak. Masa ini adalah suatu proses menuju kematangan fisik dan mental sehingga mereka siap menerima dan memberi respon terhadap stimulasi yang didapatkan dari lingkungan. Menurut Laurens (2004), lingkungan fisik sekitar seseorang sangat mempengaruhi mental dan perilakunya. Segala informasi dan stimulasi dari lingkungan akan langsung diterima sehingga memberikan pengaruh yang besar di kehidupan mereka (Suyadi, 2013). 
Dengan kata lain, lingkungan fisik memberi pengaruh penting untuk pertumbuhan dan perkembangan anak usia dini.

Sari (2004) menjelaskan bahwa lingkungan awal yang mempengaruhi pertumbuhan dan perkembangan anak tergolong menjadi dua, yaitu lingkungan rumah dan luar rumah.

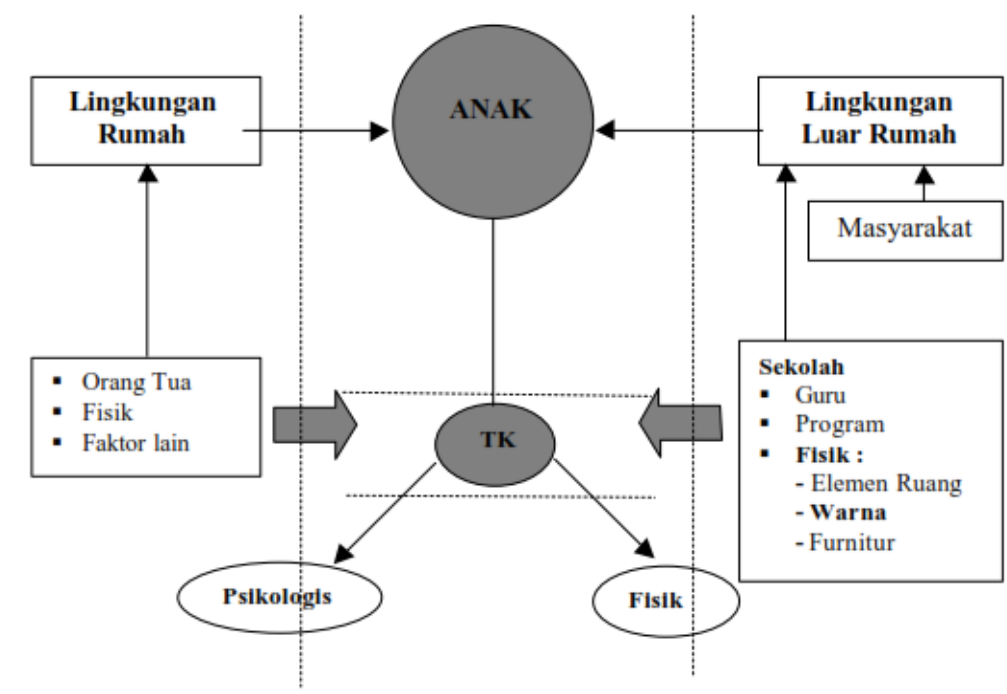

Gambar 1. Lingkungan yang Mempengaruhi Perkembangan Anak (Sumber: Sari, 2004)

Lingkungan rumah terdiri dari aspek orang tua dan fisik dari rumah. Sedangkan lingkungan luar rumah adalah masyarakat, dan lembaga formal pendidikan yaitu taman kanak-kanak (TK). Laurens (2004) menjelaskan bahwa setiap kelompok memiliki kebutuhan dasar yang berbeda sesuai penggunanya. Kebutuhan dasar anak-anak dalam berperilaku dalam sebuah lingkungan fisik berbeda dengan orang dewasa sehingga dalam sebuah lingkungan fisik pada suatu TK, dibutuhkan perlakuan yang sesuai dengan anak.

Lingkungan yang sesuai dengan perkembangan anak adalah lingkungan ramah anak. Lingkungan ramah anak adalah konsep multidimensional yang kondusif untuk belajar, dan menyediakan sarana yang sesuai dengan kebutuhan dan karakteristik anak. (UNICEF, 2009). Oleh karena itu, lingkungan yang ramah anak perlu diaplikasikan dalam bangunan sekolah, dalam hal ini adalah TK.

Menurut Kemendiknas (2009), pada sebuah lingkungan TK, kegiatan belajar dan bermain berlangsung pada ruang luar sebagai sarana aktualisasi dan eksplorasi diri dan ruang dalam untuk kegiatan belajar rutin sehingga ruang luar dan ruang dalam wajib menyediakan fasilitas yang ramah anak. Dari seluruh komponen pada ruang luar, yang mempengaruhi kegiatan belajar dan bermain anak adalah tata massa, bidang pembatas, sirkulasi, tata hijau, dan alat bermain (Olds, 2001). Menurut Sari (2004), ruang kelas penting dapat memanfaatkan elemen-elemen interior seperti pembatas ruang dan perabot untuk mendukung anak untuk belajar dan bermain. Anak membutuhkan suasana kegiatan belajar dan bermain yang menyenangkan dan menstimulasi, dengan tetap memperhatikan keamanan dan kenyamanan anak. Sehingga lingkungan ramah anak perlu diterapkan pada elemen-elemen ruang luar dan ruang dalam tersebut. 


\section{Bahan dan Metode}

Metode yang digunakan dalam mengidentifikasi kriteria lingkungan ramah anak pada sekolah TK adalah komparasi literatur. Teori-teori yang memaparkan tentang persyaratan umum lingkungan ramah anak akan dikomparasikan sehingga dapat merumuskan kriteria konsep lingkungan ramah anak. Terdapat empat teori yang dikaji, yaitu teori tentang prinsip dasar dan penyediaan sarana dan prasarana TK dari Kemendiknas (2009) dan Dirjen PAUD (2013), teori persyaratan lingkungan untuk anak dari Olds (2001), konsep lingkungan ramah anak dari UNICEF (2009), dan jurnal tentang pendidikan dan perkembangan anak oleh Sari (2004). Masing-masing teori memiliki persyaratan umum lingkungan ramah anak sebagai berikut:

Tabel 1. Komparasi Kriteria Lingkungan Ramah Anak

\begin{tabular}{|c|c|c|c|}
\hline Teori TK & UNICEF, 2009 & Sari, 2004 & Olds, 2001 \\
\hline Berorientasi pada anak & Berpusat pada anak & Bebas & Bebas bergerak \\
\hline Memotivasi anak & Aman & Aman & Nyaman \\
\hline Sesuai standar kenyamanan & Sehat & Hangat & Meningkatkan kompetensi \\
\hline \multirow[t]{2}{*}{ Sesuai standar keamanan } & Melindungi & Nyaman & Melatih kontrol diri \\
\hline & Memberi stimulasi & Rangsang & \\
\hline $\begin{array}{r}\text { (Sumber: Hasil analisis, 2014) } \\
\text { : Kriteria kea } \\
\text { Kriteria kenya } \\
\text { Kriteria stimu }\end{array}$ & $\begin{array}{l}\text { nan } \\
\text { nan }\end{array}$ & & \\
\hline
\end{tabular}

Dengan demikian dapat disimpulkan bahwa kriteria lingkungan ramah anak terdiri dari aspek keamanan, kenyamanan, dan rangsangan.

Konsep ramah anak pada sekolah TK diterapkan menggunakan metode deskriptif. Konsep ramah anak dioperasionalkan menjadi kriteria. Kriteria-kriteria tersebut dijelaskan melalui definisi operasional dan dideskripsikan lingkupnya hingga menghasilkan aspek yang lebih spesifik. Setiap aspek akan diimplementasikan menjadi indikator untuk mengidentifikasi kelemahan dan kelebihan pada elemen ruang luar dan ruang dalam yang telah disepakati.

Tabel 2. Hubungan Kriteria, Aspek, dan Elemen yang Diteliti pada Ruang Luar

\begin{tabular}{|c|c|c|c|c|c|c|}
\hline \multirow{4}{*}{ 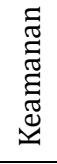 } & Aspek & Tata Massa & B. Pembatas & Sirkulasi & Alat Bermain & Tata Hijau \\
\hline & Pengawasan & $\sqrt{ }$ & - & $\sqrt{ }$ & - & - \\
\hline & Keselamatan & - & $\sqrt{ }$ & $\sqrt{ }$ & $\sqrt{ }$ & $\sqrt{ }$ \\
\hline & Kesehatan & - & $\sqrt{ }$ & - & $\sqrt{ }$ & $\sqrt{ }$ \\
\hline \multirow{5}{*}{ 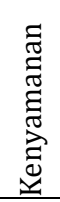 } & Aspek & Tata Massa & B. Pembatas & Sirkulasi & Alat Bermain & Tata Hijau \\
\hline & Spasial & - & $\sqrt{ }$ & - & $\sqrt{ }$ & - \\
\hline & Visual & - & $\sqrt{ }$ & $\sqrt{ }$ & - & $\sqrt{ }$ \\
\hline & Thermal & $\sqrt{ }$ & $\sqrt{ }$ & - & - & $\sqrt{ }$ \\
\hline & Akustik & $\sqrt{ }$ & $\sqrt{ }$ & - & - & $\sqrt{ }$ \\
\hline \multirow{3}{*}{ 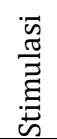 } & Sub Variabel / Aspek & Tata Massa & B. Pembatas & Sirkulasi & Alat Bermain & Tata Hijau \\
\hline & Spasial & - & $\sqrt{ }$ & - & $\sqrt{ }$ & - \\
\hline & Visual & - & $\sqrt{ }$ & - & $\sqrt{ }$ & - \\
\hline
\end{tabular}

(Sumber: Hasil analisis, 2014) 
Tabel 3. Hubungan Kriteria, Aspek, dan Elemen yang Diteliti pada Ruang Dalam

\begin{tabular}{|c|c|c|c|}
\hline \multirow{4}{*}{ 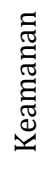 } & Aspek & B. Pembatas & Perabot \\
\hline & Pengawasan & $\sqrt{ }$ & - \\
\hline & Keselamatan & $\sqrt{ }$ & $\sqrt{ }$ \\
\hline & Kesehatan & $\sqrt{ }$ & $\sqrt{ }$ \\
\hline \multirow{5}{*}{ 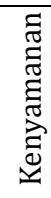 } & Aspek & B. Pembatas & Perabot \\
\hline & Visual & $\sqrt{ }$ & - \\
\hline & Spasial & $\sqrt{ }$ & $\sqrt{ }$ \\
\hline & Thermal & $\sqrt{ }$ & - \\
\hline & Akustik & $\sqrt{ }$ & - \\
\hline \multirow{3}{*}{ 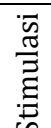 } & Aspek & B. Pembatas & Perabot \\
\hline & Spasial & $\sqrt{ }$ & $\sqrt{ }$ \\
\hline & Visual & $\sqrt{ }$ & $\sqrt{ }$ \\
\hline
\end{tabular}

\section{Hasil dan Pembahasan}

\subsection{Kriteria Keamanan}

Definisi kata aman adalah bebas dari bahaya. Sedangkan keamanan berarti keadaan aman. Jadi yang dimaksud dengan keamanan adalah keadaan yang bebas dari bahaya, baik bahaya psikologi dan fisik dari pihak ketiga, maupun bahaya psikologi dan fisik dari lingkungan itu sendiri. Berikut merupakan komparasi definisi operasional keamanan dari ketiga teori yang membahas lingkungan ramah anak:

\section{Tabel 4. Komparasi Definisi Operasional Kriteria Keamanan}

\begin{tabular}{|c|c|c|}
\hline No. & Teori & Definisi Operasional \\
\hline 1. & UNICEF (2009) & $\begin{array}{l}\text { Lingkungan belajar yang tidak higienis dan aman berbahaya untuk anak. Hal yang perlu } \\
\text { diperhatikan adalah menghindari penggunaan material berbahaya dan beracun, } \\
\text { menyediakan perabot yang ergonomis, dan pencahayaan yang memadahi. } \\
\text { Lingkungan fisik pembelajaran harus mengakomodasi anak dalam kondisi yang aman, } \\
\text { misalnya dari sumber listrik. }\end{array}$ \\
\hline 2. & Sari (2004) & $\begin{array}{l}\text { Rasa bebas berarti anak-anak tidak sulit untuk beraktivitas di dalam sebuah ruang. } \\
\text { Anak perlu merasa leluasa untuk beraktivitas dan hal ini baik untuk perkembangan } \\
\text { psikologisnya. } \\
\text { Rasa aman berarti lingkungan fisik membuat anak merasa terlindungi, tidak takut atau } \\
\text { tegang ketika melakukan kegiatan. }\end{array}$ \\
\hline 3. & Olds (2001) & $\begin{array}{l}\text { Anak perlu melatih kemampuan mengontrol diri dari lingkungan dengan cara memiliki } \\
\text { kebebasaan pribadi, melatih diri membuat prediksi, dan mengorientasikan diri mereka } \\
\text { sesuai dengan ruang yang ditempati. }\end{array}$ \\
\hline
\end{tabular}

(Sumber: UNICEF (2009), Sari (2004), Olds (2001))

Berdasarkan definisi operasional tersebut, keamanan dalam lingkungan dapat dikelompokkan menjadi tiga aspek, yaitu pengawasan, keselamatan, dan kesehatan.

\subsubsection{Keamanan pengawasan}

Pengawasan merupakan sebuah proses untuk memastikan segala aktivitas yang dilaksanakan sesuai dengan apa yang telah direncanakan (Fadhly, 2013). Jika dikaitkan dalam sebuah lingkungan, pengawasan lingkungan merupakan keadaan lingkungan yang bebas dari tindakan yang membahayakan segala aktivitas yang direncanakan maupun dilaksanakan, yang dapat terjadi karena adanya pihak lain seperti pelaku kriminal. Sehingga pada lingkungan TK, pengawasan lingkungan adalah kondisi 
lingkungan TK yang membebaskan anak dari resiko orang lain yang melakukan tindakan kriminal atau faktor lain yang membahayakan, sehingga anak dapat beraktivitas sesuai rencana. Dalam lingkungan TK, pengawasan dapat dikontrol melalui:

\section{A. Peletakan Ruang Dalam Bangunan}

Untuk mencegah adanya resiko yang membahayakan pada lingkungan TK, baik anak, tenaga pengajar, maupun orang tua harus dapat saling mengawasi melalui sebuah ruang penghubung berupa area berkumpul yang dapat memungkinkan anak, tenaga pengajar dan orang tua berkumpul dan dapat dicapai langsung melalui sirkulasi masuk utama (Olds, 2001). Posisi ruang kelas sebaiknya memiliki hirarki yang sama agar setiap ruang kelas dapat diawasi dengan baik. Berikut merupakan beberapa komparasi peletakan ruang bangunan dengan area berkumpulnya.
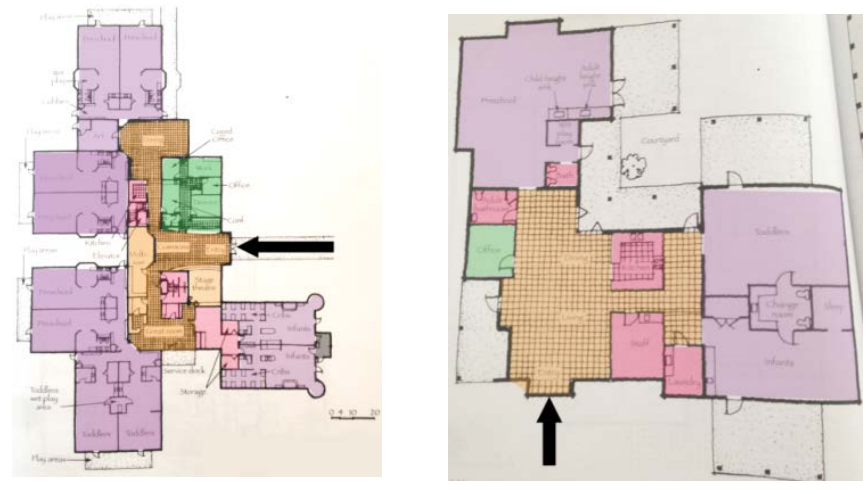

Fasilitas Utama

Fasilitas Penunjang (Area Berkumpul)

Fasilitas Pengelola

Fasilitas Servis

Gambar 2. Contoh Denah Lingkungan TK

(Sumber: Olds, 2001)

B. Pengelolaan Sirkulasi Luar dan Dalam Bangunan

Anak usia prasekolah memiliki rasa ingin tahu yang besar, sehingga lingkungan di sekitar tapak akan memberi pengaruh pada aktivitas anak. Oleh karena itu, sirkulasi menuju bangunan dan keluar bangunan harus dapat diawasi secara visual dari dalam bangunan. Sirkulasi buntu sebaiknya tidak terdapat pada bangunan karena tidak dapat terakses secara visual dan fisik sehingga menjadi ruang mati (Olds, 2001).

C. Akses Visual Dari Luar ke Dalam Ruangan

Pintu dan jendela sebaiknya menyediakan akses visual dari luar ke dalam sehingga aktivitas di dalam ruang dapat dipantau dari luar kelas terutama oleh orang dewasa (Olds, 2001).

\subsubsection{Keselamatan lingkungan}

Aspek keselamatan berasal dari kata safety yaitu kondisi bebas dari bahaya, resiko, dan luka (Wojowasito, 1980). Jika dikaitkan dengan lingkungan, keselamatan lingkungan merupakan kondisi bebas dari resiko yang berkaitan dengan nyawa manusia yang disebabkan oleh kondisi bangunan itu sendiri. Sehingga pada lingkungan TK, keselamatan lingkungan adalah kondisi lingkungan TK yang bebas dari resiko anak dari cedera maupun luka fisik saat beraktivitas, yang terdiri dari factor-faktor sebagai berikut: 
A. Pencapaian Menuju Bangunan

Anak usia prasekolah belum memiliki kontrol yang baik terhadap pergerakan dirinya sendiri, sehingga sebaiknya anak terhindar dari kontak langsung lalu lintas kendaraan karena berpotensi membahayakan keselamatan anak. Oleh karena itu pencapaian menuju bangunan sebaiknya memiliki jarak yang aman dari lalu lintas yang padat (Dirjen PAUD, 2013).

B. Permukaan material

Anak mulai mengeksplorasi kemampuan tubuh dalam melakukan gerakan fisik dasar (Kemendiknas, 2009) sehingga berpotensi untuk menabrak benda-benda di sekitarnya. Oleh karena itu, tepi dan permukaan material sebaiknya tidak tajam karena dapat melukai anak. Selain itu pada area yang melibatkan banyak gerakan motorik, material permainan sebaiknya tidak memperbesar resiko cedera pada anak.

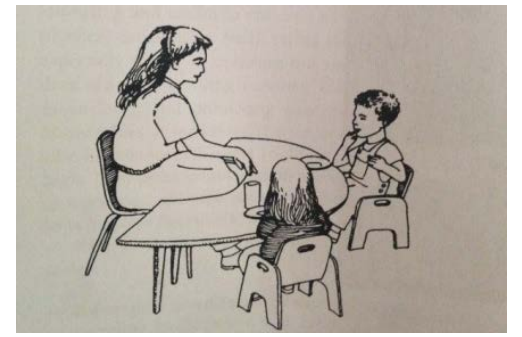

Gambar 3. Perabot Ujung Membulat Aman untuk Anak (Sumber: Olds, 2001)

C. Dimensi fixed dan semi fixed element

Menurut BP-PAUDNI (2013), anak usia prasekolah memiliki perkembangan fisik dan keingintahuan yang pesat sehingga memungkinkan anak mengembangkan eksplorasi fisik tanpa bantuan orang dewasa. Oleh karena itu, fixed dan semi fixed element sebaiknya memiliki dimensi yang tidak membahayakan anggota tubuh anak seperti terjatuh, terpeleset, maupun terjepit (Dirjen PAUD, 2013).

\subsubsection{Kesehatan lingkungan}

Aspek kesehatan adalah suatu kondisi terbebas dari gangguan jasmani, rohani, maupun sosial dengan usaha pencegahan dan pengobatan terhadap gangguan tersebut yang disebabkan oleh lingkungan. Sehingga pada lingkungan TK, kesehatan lingkungan adalah kondisi yang bebas dari gangguan yang membahayakan keadaan jasmani anak yang sehat. Pada masa kini, banyak material pada ruang kelas seperti bahan pelapis maupun perabot yang dibuat dari bahan sintetik dan menghasilkan substansi beracun yang harus dihindari.

Tabel 5. Daftar Material Mengandung Racun

\begin{tabular}{ccc}
\hline & Jenis Polusi Kimia & Material \\
No. & & \\
\hline 1. & Formalin & Particle board pada perabot, plywood, vinyl, dan cat. \\
2. & VOC & Beberapa jenis cat dan karpet \\
3. & Asbestos & Asbes \\
4. & Radon & Gypsum \\
5. & Lead & Beberapa jenis cat \\
\hline (Sumber: Olds, 2001)
\end{tabular}




\subsection{Kriteria Kenyamanan}

Definisi operasional kenyamanan adalah kondisi dimana pelaku aktivitas (dalam hal ini anak usia prasekolah) tetap mau dan mampu beraktivitas (Sari, 2004). Berikut merupakan komparasi definisi operasional kenyamanan dari ketiga teori yang membahas lingkungan ramah anak:

Tabel 6. Komparasi Definisi Operasional Kriteria Kenyamanan

\begin{tabular}{lll}
\hline No. & Teori & Definisi Operasional \\
\hline 1. & UNICEF (2009) & $\begin{array}{l}\text { Lingkungan sekolah tidak nyaman atau bahkan mengancam, akan membawa } \\
\text { penderitaan pada jiwa anak. Secara umum, lingkungan yang ramah dan melindungi } \\
\text { anak tidak hanya kondusif untuk belajar, namun juga untuk bermain dan berinteraksi } \\
\text { secara nyaman. }\end{array}$ \\
\hline 2. & Sari (2004) & $\begin{array}{l}\text { Rasa nyaman berarti mengkondisikan seorang anak untuk tetap beraktivitas selama ia } \\
\text { mau dan mampu. }\end{array}$ \\
\hline 3. & Olds (2001) & $\begin{array}{l}\text { Saat anak merasa nyaman berada di lingkungan fisik sekitarnya., mereka akan } \\
\text { memberanikan diri mengeksplorasi material atau kejadian disekitarnya. }\end{array}$ \\
\hline (Sumber: UNICEF (2009), Sari (2004), Olds (2001))
\end{tabular}

Dalam sebuah lingkungan, aspek kenyamanan fisik dapat dikategorikan sebagai berikut:

\subsubsection{Kenyamanan spasial}

Kenyamanan ruang yang dimaksud adalah kondisi ideal antara antropometri tubuh manusia dan aktivitas yang disesuaikan dengan fungsi ruangan. Suatu ruang dalam lingkungan harus dapat memenuhi persyaratan antropometri, pembedaan dan pengelompokan fungsi untuk aktivitas manusia. Dalam lingkungan TK, agar ruang-ruang aktivitas dapat memberi kenyamanan untuk anak, faktor yang perlu diperhatikan adalah sebagai berikut:

A. Antropometri Anak Usia Prasekolah

Rentang dan jangkauan tubuh anak usia prasekolah akan mempengaruhi luas tapak dan bangunan yang ideal untuk beraktivitas, serta ergonomi perabot. Dimensi perabot disesuaikan dengan kebutuhan pelaksanaan pendidikan dan ukuran tubuh anak didik. Data yang didapat dari Direktorat Kesehatan Gizi Depkes RI (2011), ratarata tinggi badan anak usia 4 tahun adalah $103.5-108 \mathrm{~cm}$. Tinggi badan anak usia 5 tahun adalah $109 \mathrm{~cm}$. Berikut merupakan data bentang tubuh anak usia $4-6$ tahun.

Tabel 7. Daftar Ukuran Tubuh Anak Usia 4 - 6 Tahun

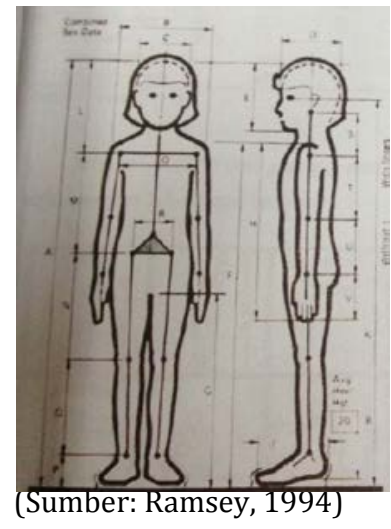

\begin{tabular}{llllllll}
\hline & $\begin{array}{l}\text { Besar } \\
(\mathrm{cm})\end{array}$ & $\begin{array}{l}\text { Rata- } \\
\text { Rata } \\
(\mathrm{cm})\end{array}$ & $\begin{array}{l}\text { Kecil } \\
(\mathrm{cm})\end{array}$ & & & & \\
\hline $\mathrm{A}$ & 118,5 & 109,0 & 99,5 & $\mathrm{~L}$ & 27 & 25,5 & 24 \\
\hline $\mathrm{B}$ & 29 & 26 & 23 & $\mathrm{M}$ & 31,5 & 30 & 28 \\
\hline $\mathrm{C}$ & 14,5 & 13,5 & 12,5 & $\mathrm{~N}$ & 26 & 23,5 & 21 \\
\hline $\mathrm{D}$ & 19,5 & 18 & 16,5 & $\mathrm{O}$ & 25,5 & 22 & 19,5 \\
\hline $\mathrm{E}$ & 20 & 19,5 & 19 & $\mathrm{P}$ & 8,5 & 8 & 7 \\
\hline $\mathrm{F}$ & 94,5 & 86,5 & 78 & $\mathrm{Q}$ & 21,5 & 20 & 18,5 \\
\hline $\mathrm{G}$ & 54,5 & 49 & 43 & $\mathrm{R}$ & 10,5 & 9 & 8 \\
\hline $\mathrm{H}$ & 51,5 & 46 & 41,5 & $\mathrm{~S}$ & 13,5 & 12,5 & 12 \\
\hline $\mathrm{J}$ & 18,1 & 16,1 & 14,1 & $\mathrm{~T}$ & 19 & 17 & 14,5 \\
\hline $\mathrm{K}$ & 108,5 & 99,5 & 89 & $\mathrm{U}$ & 16 & 14,5 & 13 \\
\hline L & & & & $\mathrm{V}$ & 13 & 12 & 11,5 \\
\hline & & & & & & & \\
\hline
\end{tabular}


Tabel 8. Ukuran Rentang Tubuh Anak Saat Beraktivitas

\begin{tabular}{|c|c|c|c|c|c|c|c|}
\hline & & Besar & $\begin{array}{l}\text { Rata } \\
\text { Rata }\end{array}$ & - $\quad$ Kecil & & Besar & $\begin{array}{lll}\text { Rata } & \text { - Kecil } \\
\text { Rata } & \\
\end{array}$ \\
\hline $\mathrm{A}$ & High reach & 133 & 121 & 108,5 & $\mathrm{~J}$ & Work top & 57 \\
\hline $\mathrm{B}$ & Low reach & 50 & 46,5 & 42,5 & $\mathrm{~K}$ & Work depth & 33 \\
\hline $\mathrm{C}$ & Reach distance & 48 & 43,5 & 86,5 & $\mathrm{~L}$ & Table height & 44,5 \\
\hline $\mathrm{D}$ & High reach & 97 & 91,5 & 34,5 & $\mathrm{M}$ & Seat height & 26,5 \\
\hline$E$ & Reach radius & 43 & 38,5 & 72 & $\mathrm{~N}$ & Seat to backrest & 12 \\
\hline $\mathrm{F}$ & Eye level & 81,5 & 77 & - & 0 & Backrest height & 12,5 \\
\hline $\mathrm{G}$ & Shelf height & & 109 & & $\mathrm{P}$ & Armrest spacing & 30,5 \\
\hline $\mathrm{H}$ & Lavatory height & & 48,5 & & $Q$ & Seat width & 28 \\
\hline
\end{tabular}

(Sumber: Ramsey, 1994)

B. Pengelompokan dan Pembedaan Zona Aktivitas

Dalam suatu lingkungan TK, aktivitas anak sangat beragam dan berbeda, sehingga terbentuklah sebuah pola perilaku yang kompleks dalam satu ruangan dengan kebutuhan fisik yang berbeda, sehingga tiap zona perlu memiliki definisi spasial yang berbeda dengan memperhatikan kejelasan batas, suasana dan material elemen ruang sesuai aktivitas untuk memperjelas perbedaan zona agar mudah diidentifikasi.

Tabel 9. Jenis Aktivitas dalam Setiap Zona Ruang

\begin{tabular}{|c|c|c|}
\hline No. & Zona & Aktivitas \\
\hline & Entry Zone & $\begin{array}{l}\text { Transisi dari luar ke dalam ruangan, sehingga terjadi aktivitas } \\
\text { penyesuaian perlengkapan baik pakaian maupun peralatan } \\
\text { bermain. }\end{array}$ \\
\hline 2. & Messy Zone & $\begin{array}{l}\text { Menggunakan material yang bersifat basah dan rawan mengotori } \\
\text { seperti air, pasir, maupun cat. }\end{array}$ \\
\hline 3. & Active Zone & $\begin{array}{l}\text { Bersifat fisik dan melatih motorik seperti senam, bermusik, } \\
\text { hingga permainan drama. }\end{array}$ \\
\hline & Quite Zone) & $\begin{array}{l}\text { Lebih mengedepankan konsentrasi dan fokus seperti matematika } \\
\text { atau membaca, dan bahkan yang berhubungan dengan istirahat. }\end{array}$ \\
\hline
\end{tabular}

(Sumber: Olds, 2001)

Dalam meletakkan area aktivitas dalam ruangan, ditentukan dari kesesuian antara aktivitas yang terjadi dan peletakannya dalam ruangan. Menurut Olds (2001), hal pertama yang harus dilakukan untuk menentukan peletakan area aktivitas adalah menentukan area terlindung dan terbuka. Area terlindung sesuai untuk aktivitas yang tenang yang terdapat pada quite zone, dan permainan menyusun balok. Sedangkan area terbuka yang dekat dengan sirkulasi utama pada ruang kelas sesuai untuk aktivitas pada messy zone dan active zone. Pada intinya, aktivitas yang memiliki kontras seperti ramai - tenang atau bersih - kotor harus dipisahkan.

C. Kapasitas Area Bermain

Menurut Olds (2001) ruang luar sebaiknya menyediakan area bermain dengan kapasitas sesuai aktivitas, yaitu area privat yang dapat digunakan oleh anak seorang diri (namun tetap memiliki akses visual), area kelompok kecil (2 - 4 anak), area untuk kegiatan klasikal motorik (10 anak), aula ( $>10$ orang), dan area bebas untuk berkumpul secara informal.

D. Kelengkapan Alat Bermain

Untuk menciptakan aktivitas bermain yang optimal sebaiknya sebuah lingkungan TK menyediakan sarana dengan beberapa tipe aktivitas berdasarkan kebutuhan elemen fisiknya, yang terdiri dari sarana dengan elemen alam seperti pasir, air, dan vegetasi 
untuk belajar mengobservasi dan bermain, alat permainan aktif untuk pengembangan motorik, permainan struktur, dramatik, imajinatif untuk melatih motorik halus, dan area menenangkan diri sekaligus berpiknik.

\subsubsection{Kenyamanan Visual}

Kenyamanan visual adalah kenyamanan pelaku aktivitas dalam melihat objek dalam ruang. Untuk menciptakan suatu kenyamanan visual pada ruang luar, bangunan TK perlu memiliki sebuah pencitraan bangunan yang memang diciptakan untuk anak (Olds, 2001). Aspek yang perlu diperhatikan untuk menciptakan citra bangunan untuk anak pada lingkungan TK adalah sebagai berikut:

A. Kesesuaian Suasana

Menurut Olds (2001), untuk menciptakan citra bangunan untuk anak, dapat ditempuh dengan berbagai cara. Bangunan untuk anak sebaiknya memiliki transisi yang baik dengan lingkungan, dengan cara menempatkan vegetasi untuk menyamarkan batas bangunan dan tapak. Sirkulasi yang menghubungkan jalan ke dalam bangunan, perlu menawarkan sebuah pengalaman ruang berupa pengalaman sensorik dan spasial yang menyenangkan untuk diingat karena kemauan anak beradaptasi pada lingkungan baru ditentukan dengan kesan mereka terhadap jalur masuknya. Penggunaan material alami (kayu, batu bata, dan plesteran) pada bagian yang terjangkau anak lebih hangat dan menciptakan kenyamanan dibandingkan pengunaan material pabrikasi (baja maupun alumunium) yang menghadirkan suasana industrial yang terkesan dingin.

B. Kesesuaian Skala

Skala mengacu pada dimensi elemen arsitektural seperti panjang sirkulasi, ketinggian atap, pintu, dan jendela. Skala residensial memiliki ukuran yang lebih mendekati ukuran tubuh manusia dibandingkan skala institusional yang sering ditemukan di gedung bertingkat, sehingga skala residensial memiliki karakteristik hangat yang lebih sesuai untuk anak.

Pada ruang dalam, kenyamanan visual berhubungan dengan kuantitas dan kualitas penerangan yang sesuai dengan fungsi ruang, sehingga aspek yang mempengaruhi adalah pencahayaan. Menurut Mulyati (2010), yang harus diperhatikan pada pencahayaan alami adalah:

A. Jumlah Bukaan

Menurut data SNI, banyak lubang cahaya ideal untuk memasukkan cahaya alami adalah $20 \%$ dari luas seluruh dinding. Jika terlalu banyak cahaya yang masuk maka ruangan akan menjadi tidak nyaman karena silau.

B. Letak Bukaan

Pencahayaan alami dapat diatur dengan memperhitungkan arah bukaan. Peletakan bukaan juga ditentukan oleh fungsi dari ruang dalam. Cahaya matahari dapat dimanfaatkan sesuai dengan fungsi ruangnya untuk mendukung aktivitas dalam ruang.

C. Warna Finishing Material

Warna finishing material yang digunakan mempengaruhi tinggi rendahnya refleksi atau pantulan cahaya matahari. Warna terang lebih banyak memantulkan cahaya daripada warna gelap. 


\subsubsection{Kenyamanan thermal}

Kenyamanan thermal merupakan kemampuan lingkungan buatan dalam memberi kenyamanan yang berkaitan dengan iklim dan kalor. Menurut Mulyati (2010), untuk mencapai kenyamanan thermal pada ruang luar, aspek yang diperhatikan adalah sebagai berikut:

A. Penggunaan Material Bangunan

Dalam membangun bangunan, material alami yang tebal membawa efek yang positif pada suhu udara dibandingkan material pabrikasi, karena bahan alam tidak mengalami banyak proses pembuatan.

B. Peletakan Vegetasi

Dalam bangunan TK, ruang kelas perlu mendapatkan suhu yang nyaman untuk beraktivitas. Vegetasi tinggi diletakkan di tepi tapak untuk mendinginkan suhu udara luar sebelum masuk ke dalam ruangan. Vegetasi berdaun lebat dan tidak terlalu tinggi sebaiknya diletakkan di dekat bukaan ruang kelas agar dapat berfungsi secara optimal menyaring udara kotor.

C. Pengaturan Tata Massa

Konsep tata massa open space dapat membuat udara bebas mengalir ke seluruh ruang sehingga setiap kelas mendapat intensitas aliran udara yang sama.

Menurut Mulyati (2010), dalam desain ruang dalam, untuk memberi kenyamanan suhu dalam ruangan dapat dilakukan dengan:

A. Letak Bukaan

Bukaan seperti pintu, jendela, dan ventilasi berfungsi untuk pertukaran udara, sebaiknya diletakkan ke arah datangnya angin dan dua sisi yang berseberangan.

B. Ukuran Bukaan

Berdasarkan data SNI, jumlah bukaan minimal 10\% dari luas lantai.

\subsubsection{Kenyamanan akustik}

Kenyamanan akustik berkaitan dengan penanggulangan kebisingan yang berpotensi mengganggu aktivitas, karena anak usia prasekolah sangat peka terhadap bunyi. Pada ruang luar, kenyamanan akustik dapat ditempuh dengan cara menahan kebisingan yang menuju ke dalam tapak dan berasal dari lingkungan sekitar. Menurut Mulyati (2010), hal-hal yang harus diperhatikan untuk mencapai kenyamanan akustik pada ruang luar adalah sebagai berikut:

A. Pagar Pembatas

Pagar pembatas dengan variasi material pagar, dinding bata, dan vegetasi dapat membantu memecah kebisingan yang datang dari luar seperti kendaraan dan fasilitas umum.

B. Peletakan Tata Massa

Ruang - ruang kelas membutuhkan perlindungan khusus dari kebisingan sehingga dapat diletakkan pada area yang jauh dari kebisingan.

Pada ruang dalam, kenyamanan akustik berkaitan dengan penganggulangan bunyi yang berpotensi aktivitas yang berasal dari ruang itu sendiri berupa gema dan gaung.

Menurut Mulyati (2010), Penyebaran bunyi ditentukan oleh elemen pembatas ruangan. Elemen pembatas ruangan memiliki karakter memantulkan, menyerap, atau mentransmisikan bunyi. Plafon sebaiknya menggunakan bahan yang tidak mudah 
berlubang, karena dapat mentrasmisikan bunyi dari luar. Plafon gantung dapat membantu meredam bunyi. Dinding harus memiliki massa yang cukup tebal dan luas untuk menyebarkan bising udara. Sebaiknya dinding non struktural dihindari karena mudah bergetar sehingga bunyi dapat menyebar. Pelat lantai bertingkat dapat membantu meredam bunyi, seperti lantai yang berlapis majemuk dimana terdapat selimut penenang (sound absorbsing felt) diantara pelat lantai dan lantai.

\section{3. $\quad$ Kriteria Stimulasi}

Stimulasi pada lingkungan TK adalah sebuah cara untuk menciptakan sebuah lingkungan yang dapat merangsang anak untuk mengeksplorasi material maupun kejadian-kejadian di sekitarnya. Berikut merupakan komparasi definisi operasional stimulasi dari ketiga teori yang membahas lingkungan ramah anak:

Tabel 4. Komparasi Definisi Operasional Kriteria Stimulasi

\begin{tabular}{|c|c|c|}
\hline No. & Teori & Definisi Operasional \\
\hline 1. & UNICEF (2009) & $\begin{array}{l}\text { Menyadari kebutuhan anak secara holistik maupun koheren, memadukan karakteristik } \\
\text { anak untuk dikontribusikan dalam keberagaman dari pembelajaran di sekolah. }\end{array}$ \\
\hline 2. & Sari (2004) & $\begin{array}{l}\text { Rangsang berarti ruang bertindak sebagai faktor eksternal yang dapat membantu } \\
\text { proses perkembangan potensi anak melalui kegiatan kreatifnya. Sebuah ruang } \\
\text { hendaknya mampu menjadi sumber gagasan, imajinasi bagi anak. Rangsang sangat } \\
\text { penting sebagai stimuli luar sehingga membantu produktifitas anak yang berguna bagi } \\
\text { perkembangannya. }\end{array}$ \\
\hline 3. & Olds (2001) & $\begin{array}{l}\text { Lingkungan wajib memungkinkan anak untuk melakukan pergerakan otot dengan } \\
\text { berbagai variasi gerakan baik di luar maupun dalam ruangan. Suasana di sekitar harus } \\
\text { merangsang anak untuk bergerak namun tetap tetap aman. Lingkungan yang suportif } \\
\text { membantu mereka anak memenuhi kebutuhan, mengerjakan tugas, mengatur peralatan } \\
\text { dan pergerakan mereka }\end{array}$ \\
\hline
\end{tabular}

(Sumber: UNICEF (2009), Sari (2004), Olds (2001))

Untuk memberi stimulasi kepada anak, lingkungan harusnya tidak seharusnya terlalu monoton, atau terlalu variatif, namun terdapat sebuah perbedaan yang disebut kontras untuk membuat lingkungan menjadi menyenangkan. Menurut Olds (2001), stimulasi yang dapat dirasakan oleh anak adalah sebagai berikut:

\subsubsection{Stimulasi spasial}

Stimulasi spasial dapat didefinisikan sebagai perbedaan/ variasi spasial sehingga anak merasakan perubahan yang dinamis pada ruang. Stimulasi berupa kontras ini dapat diterapkan baik pada ruang luar maupun ruang dalam.

A. Kontras Dalam/ Luar

Kontras dalam/ luar merupakan perbedaan dimensi yang mengacu pada tingkat tertutup dan terbukanya suatu elemen bangunan dengan perbedaan ruang dalam, ruang luar, dan ruang transisi. Selain itu dapat juga dicapai dengan perbedaan fisik berupa ruang yang terekspos dan terlindungi.

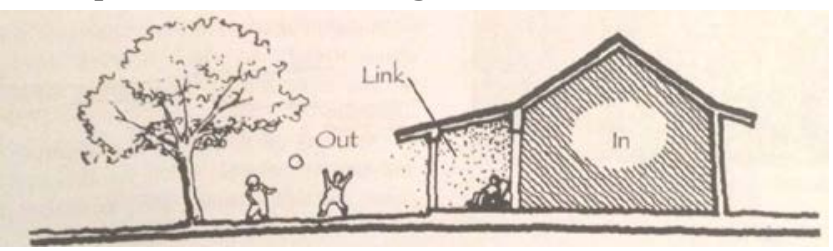

Gambar 4. Kontras Dalam/ Luar

(Sumber: Olds, 2001) 
B. Kontras Atas/ Bawah

Kontras atas/ bawah dapat didefinisikan sebagai perbedaan dimensi yang menekankan bagaimana keberadaan sebuah bidang dalam bangunan mengacu pada ketinggian bidang alas bawah dan atasnya.

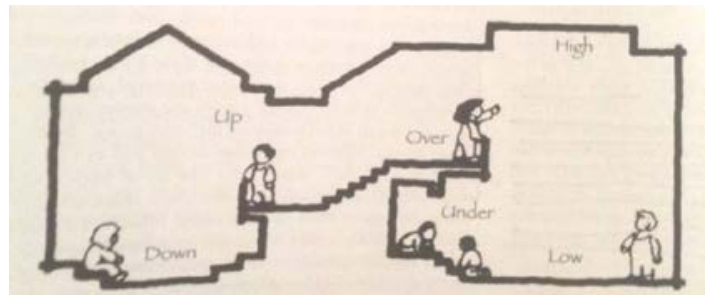

Gambar 5. Kontras Atas/ Bawah (Sumber: Olds, 2001)

C. Kontras Prediksi/ Teka - Teki

Kehadiran aspek keteraturan dihadirkan dengan elemen bangunan yang mudah terprediksi dan sesuai dengan ketentuan. Sedangkan aspek teka-teki direfleksikan dengan sesuatu yang lebih lunak dan ambigu dan mengundang rasa penasaran anak sehingga tertarik untuk mencari tahu karena tidak mudah terprediksi.

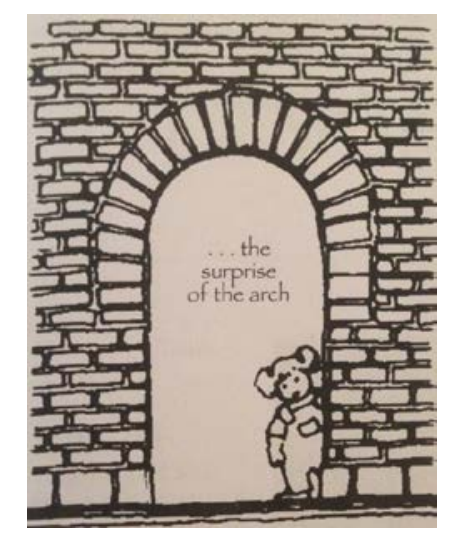

Gambar 6. Kontras Prediksi/ Teka - Teki (Sumber: Olds, 2001)

\subsubsection{Stimulasi visual}

Kontras visual dapat didefinisikan sebagai variasi elemen-elemen visual yang bersifat menyenangkan dan memberi rangsangan positif kepada anak. Elemen yang harus diperhatikan dalam memberi kontras visual adalah

A. Penggunaan Warna yang Memberi Stimulasi

Keingintahuan, kreativitas, dan imajinasi sedang berkembang pesat menjadi kesan yang harus dihadirkan melalui elemen arsitektural, terutama warna. Warna cerah dengan hue murni akan menarik anak namun berpotensi membuat anak hiperaktif dan mudah lelah. Menurut Kopacz (2004), dominasi warna dari kelompok warna hangat dengan pigmen yang telah diberi variasi value dan intensity, sesuai digunakan sebagai dominasi warna pada lingkungan TK karena lebih membangkitkan semangat dibandingkan kelompok warna sejuk yang lebih sejuk dan tenang. Skema warna polikromatik yang memiliki warna kontras seperti komplementer atau triadik lebih sesuai digunakan karena memberi dibandingkan skema warna akromatik karena 
mengandung warna dari dua kelompok warna yang berbeda, sehingga dapat memberi keseimbangan antara memberi kontras, namun juga menenangkan.
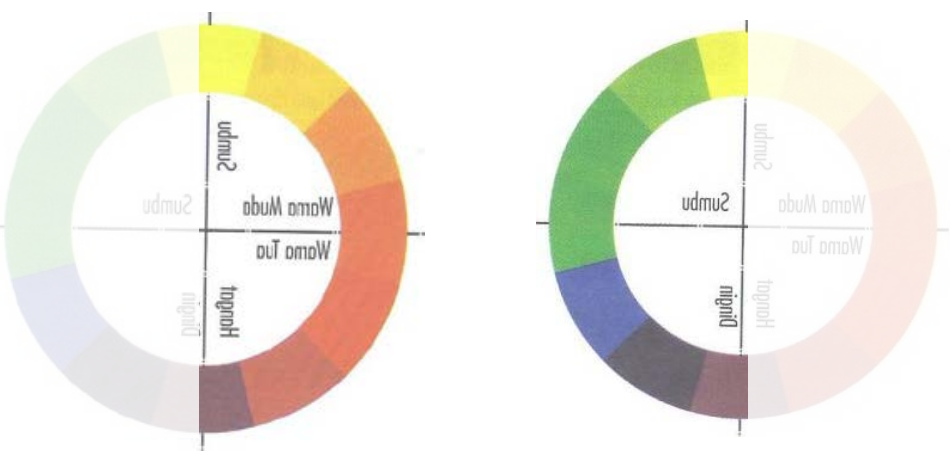

Gambar 7. Kelompok Warna Panas (Kiri) dan Kelompok Warna Dingin (Kanan) (Sumber: Ching, 2005)
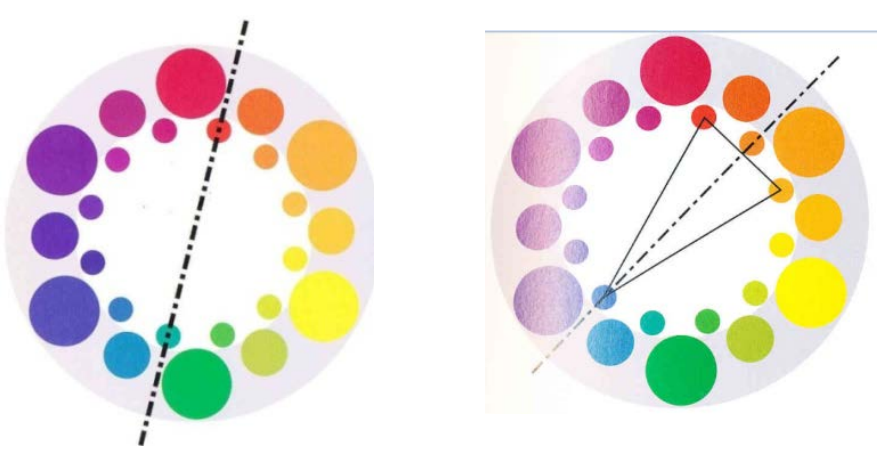

Gambar 8. Skema Warna Komplementer (Kiri) dan Split Komplementer (Kanan) (Sumber: Kopacz, 2004)
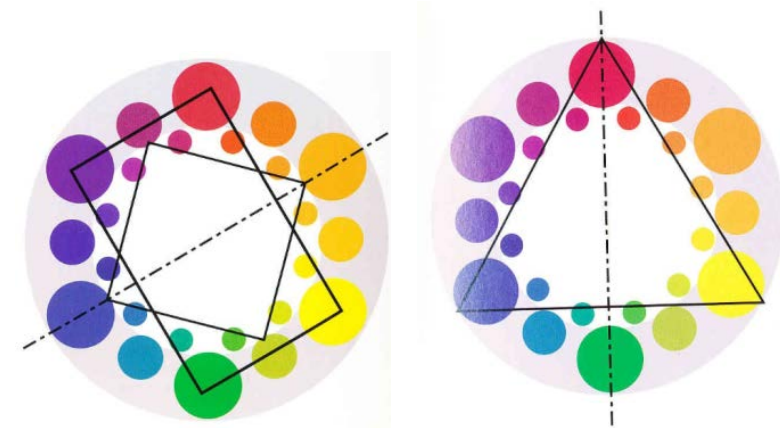

Gambar 9. Skema Warna Double Split Komplementer (Kiri) dan Triadik (Kanan) (Sumber: Kopacz, 2004)

B. Penggunaan Variasi Bentuk

Menurut Olds (2001), perbedaan bentuk dalam arsitektural memberi makna yang berbeda. Bentuk lengkung, melambangkan sesuatu yang dinamis. Bentuk segitiga/ bersudut, melambangkan teknologi. Bentuk segi empat, melambangkan bumi. Ketiga bentuk tersebut perlu dihadirkan sesuai kebutuhan pada sebuah lingkungan TK, terutama bentuk lengkung karena bersifat membangkitkan semangat anak. 


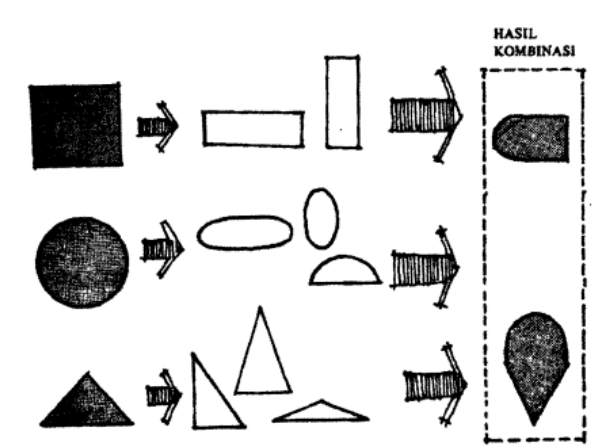

Gambar 10. Komposisi Tiga Bentuk Dasar

(Sumber: Hakim, 2003)

C. Penggunaan Variasi Tekstur

Tekstur dari material adalah yang terkena kontak fisik dengan anak sehari-hari. Sebuah fasilitas untuk anak harus menawarkan kekayaan tekstur baik dari material alami maupun pabrikasi. Penggunaan pengolahan tekstur pada ruang luar dan ruang dalam dapat dilakukan pada pembatas ruang maupun sirkulasi. Sebagai contoh, tekstur lantai dapat membantu anak untuk membedakan ruang gerak/ sirkulasi dan ruang statis (Hakim, 2003)

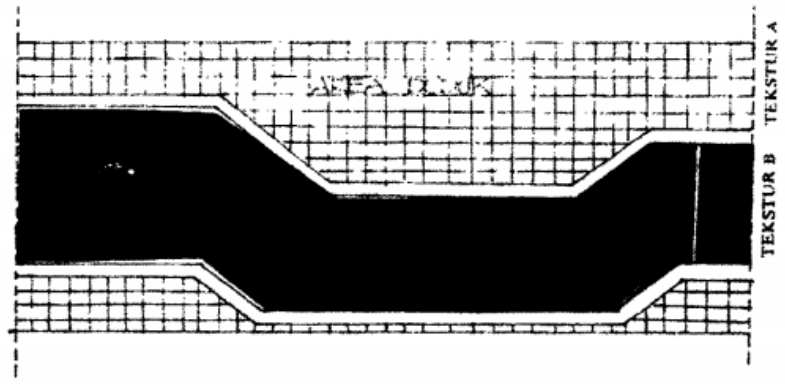

Gambar 11. Perbedaan Tekstur Lantai pada Area Sirkulasi

(Sumber: Hakim, 2003)

\section{Kesimpulan}

Berdasarkan penelitian yang dilakukan, maka dapat disimpulkan bahwa konsep sekolah ramah anak adalah sebuah konsep terutama elemen fisik yang memperhatikan karakteristik dan kebutuhan mendasar anak. Kriteria konsep sekolah ramah anak yang didapatkan dari komparasi teori adalah keamanan, kenyamanan, dan stimulasi. Elemen ruang luar yang mempengaruhi berlangsungnya aktivitas anak pada TK adalah tata massa, bidang pembatas, sirkulasi, tata hijau, dan alat bermain. Sedangkan elemen ruang dalam (ruang kelas) yang mempengaruhi berlangsungnya aktivitas adalah bidang pembatas berupa (plafon, dinding, dan lantai) dan perabot.

Kriteria keamanan mencakup aspek keamanan pengawasan, keselamatan lingkungan, dan kesehatan lingkungan. Pada aspek keamanan pengawasan, yang harus diperhatikan adalah kemudahan akses fisik dan visual pada tata massa, sirkulasi, dan ruang kelas dalam mengawasi aktivitas anak. Pada aspek keselamatan lingkungan, yang harus diperhatikan adalah jarak sirkulasi dan permukaan material bidang pembatas, tata hijau, alat bermain dan perabot yang tidak membahayakan/ mencederakan anak. Pada aspek kesehatan lingkungan, yang harus diperhatikan adalah material bidang pembatas, tata hijau, alat bermain, dan perabot bebas dari racun. 
Kriteria kenyamanan mencakup aspek kenyamanan spasial, visual, thermal, dan akustik. Pada aspek kenyamanan spasial, yang harus diperhatikan adalah pembedaan zona aktivitas, kelengkapan sarana dan dimensi alat bermain. Pada aspek kenyamanan visual, yang harus diperhatikan adalah kenyamanan suasana dan skala elemen bangunan, dan pencahayaan alami pada ruang kelas. Pada aspek kenyamanan thermal, yang perlu diperhatikan adalah kenyamanan suhu ideal ruang luar dan dalam yang terlindung dari udara dan panas matahari yang berlebih. Pada aspek kenyamanan akustik, yang perlu diperhatikan adalah konstruksi elemen pembatas ruang dan tata massa dalam memecah kebisingan.

Kriteria stimulasi mencakup aspek stimulasi spasial dan visual. Pada aspek stimulasi spasial, yang harus diperhatikan adalah pemberian definisi spasial pada bidang pembatas, alat bermain dan perabot. Pada aspek stimulasi visual, yang harus diperhatikan adalah pemberian warna yang memberi stimulasi dan variasi bentuk dan tekstur pada bidang pembatas, alat bermain, dan perabot.

Secara umum, kriteria ramah anak yang harus diperhatikan dalam lingkungan TK adalah layout bangunan yang mudah terawasi, material (mencakup permukaan yang tidak licin dan substansi yang bebas racun, dan pemberian kontras yang menstimulasi.

\section{Daftar Pustaka}

BP-PAUDNI. 2013. Teori Perkembangan pada Masa Pra-Sekolah dan Fase Sekolah. http://www.bppaudnibanjarbaru.org (diakses 15 Desember 2014)

Ching, Francis D.K. 2005. Ilustrasi Desain Interior. Jakarta: Erlangga.

Direktorat Jendral PAUD. 2013. Petunjuk Teknis Penyelenggaraan Taman Kanak Kanak. Jakarta

Direktorat Kesehatan Gizi Depkes RI. 2011. http://www.gizikia.kemkes.go.id (diakses 15 Desember 2014)

Fadhly. 2013. 39 Pengertian Pengawasan. http://iamfadhli.wordpress.com (diakses tanggal 17 Juni 2014).

Hakim, Rustam. 2003. Komponen Perancangan Arsitektur Lansekap. Jakarta: Bumi Aksara.

Kementerian Pendidikan Nasional. 2009. Peraturan Menteri Pendidikan Nasional No. 58 Tahun 2009 Tentang Standar Pendidikan Anak Usia Dini. Jakarta: Sekretariat Negara

Kopacz, Jeanne. 2004. Colour in Three Dimensional Design. New York: McGraw-Hill.

Laurens, Joyce Marcella. 2004. Arsitektur dan Perilaku Manusia. Jakarta: PT. Grasindo.

Mulyati. 2010. Hemat Energi Melalui Pencahayaan dan Penghawaan. Denpasar: Sari Kahyangan Indonesia.

Olds, Anita Rui. 2001. Child Care Design Guide. New York: The Mc Graw-Hill Companies, Inc.

Ramsey. 1994. Architectural Graphic Standards. New York: John Wiley \& Sons, Inc.

Suyadi. 2013. Konsep Dasar PAUD. Jogjakarta: Rosda.

Sari, Sriti Mayang. 2004. Peran Warna Interior Terhadap Perkembangan dan Pendidikan Anak di Taman Kanak-Kanak. Karya Tulis Ilmiah, Jurnal Dimensi Interior Vol.2, No.1. Surabaya: Puslit Univ. Kristen Petra.

UNICEF. 2009. Childs Friendly Schools Manual. New York: UNICEF's Division of Communication

Wojowasito, S., Poerwadarminta, W.J.S., Wasito, Tito. 1980. Kamus Lengkap Inggris Indonesia Indonesia - Inggris. Bandung: C.V Hasta. 